Perspective, part of a special feature on The Science and Practice of Ecology and Society

\title{
Twenty Years of Interdisciplinary Studies: the "MEZA" Program's Contributions to Society, Ecology, and the Education of Postgraduate Students
}

\author{
César Vázquez ${ }^{2}$, Critiane Aguilar, Héctor Benet, Rosa Carmona, Tania de la Vega, Hugo Espinosa, Miguel Flores, \\ Pablo Franco, Itzel Frias, Jenny Guzmán, Alfa Hernández, Adriana Licona, Francisco Martínez, Ailed Maymes, \\ Marina Mondragón, Tatiana Montano, Lourdes Ojeda, Adriana Ríos, Erick Rochín, Laura Rodríguez, Natalia Rodríguez, \\ Roberto Romero, Fernando Solis, Soledad Valdés, and Iván Velázquez
}

\begin{abstract}
Management of arid ecosystems (MEZA by its Spanish acronym) is a Master of Science program that started in 1990 when very few interdisciplinary programs in environmental management existed in the world. Graduates and current students recognize the importance of a group of pioneers in multidisciplinary practice who have translated the scientific findings and insights of a diverse scholarly community into practical applications within the city in which the University of Baja California, El Sauzal campus, is located and its surrounding arid and coastal rural areas. Students and teachers have produced 20 ecosystem management plans, which have trained the students in practical teamwork. Most of these plans addressed an inquiry by a local community or government decision maker, which is considered to be the key origin of a project. In this paper, the MEZA program that the teachers designed is briefly described, and a series of projects are given as examples of their work. Two projects are more thoroughly explained because all of the coauthors (2009 and 2010 students) participated in these projects and believe that it is a valuable experience to share with others.
\end{abstract}

Key Words: ecosystem management; Ensenada-Baja California; local knowledge; local participation; management planning; multidisciplinary research

\section{INTRODUCTION}

The purpose of this paper is to acknowledge the training of 23 students (the coauthors) by the teachers of the Management of Arid Ecosystems (MEZA, by its Spanish acronym) Master of Science program. MEZA was founded in 1990 by the coastal ecosystem ecologist Ileana Espejel and the agronomist José de Jesús Castellón. Its main objective was to explore new ways to teach ecosystems management from a multidisciplinary perspective, focusing on the arid and coastal region of Baja California in northern Mexico. The program has evolved. The social sciences are not optional as they were initially, and other Mexican and Latin-American countries and ecosystems have been included. The size of the teachers' team has doubled and the teachers have become experts in multidisciplinary thinking; many former students are now teachers in the program. Additionally, MEZA is now associated with other postgraduate programs: specialization in environmental management (manejo.ens.uabc.mx/ESPECIALIDAD/index.htm ) and a doctoral program in environment and development ( ambiente.ens.uabc.mx/Bienvenida.html). Every program is recognized by CONACyT, a Mexican Science Foundation, MEZA as a consolidated program. Dr. Espejel still leads the academic team (Table 1, Fig. 1).

The formation of the teams especially at the master's level has benefitted the ecosystems of coastal areas (Chircop 2000) and watershed basins (http://www.watershed.org/). Since the mid-1970s, there have been interdisciplinary Master of Science-level programs in Mexico that are focused on natural resource management. Among the pioneering programs was the Instituto Nacional de Investigaciones En Recursos Bióticos's (National Institute of Biotic Resources) Biotic Resources Master Program founded by the tropical ecosystems ecologist Arturo Gómez-Pompa (www.reservaele den.org/agp/) and the Rural Development Master Program at the Colegio de posgraduados founded by Efraín HernándezXolocotzin (www.ibiologia.unam.mx/jardin/gela/page4.html ), an agronomist in tropical México. Unfortunately, the experiences of these interesting initial programs and other more recent programs have not been published.

Recently, the Network of Pluridisciplinary Postgraduate Programs was formed by an initiative of the MEZA team, and symposia were organized (4simposioposg-interdisciplinarios. blogspot.com/). The result of the first symposium was published (Espejel et al. 2005) and focused on the difficulties of evaluating a multidisciplinary teaching program. During the fourth symposium, students described their experiences and compared the MEZA program with the other multidisciplinary educational programs' presentations. It was this experience that motivated us to demonstrate the MEZA team's success to international readers.

From its inception, MEZA research was based on a process of "learning by doing" and what is now known as "postnormal" 
Table 1. MEZA Teachers.

\begin{tabular}{|c|c|c|}
\hline & Teachers & Academic Areas \\
\hline \multirow{2}{*}{\multicolumn{3}{|c|}{$\begin{array}{l}\text { FOUNDERS, MAIN GROUP } \\
\text { Sciences School }\end{array}$}} \\
\hline & & \\
\hline & Claudia Leyva & Environmental education \\
\hline & Roberto Martínez & Wildlife management \\
\hline & Evarista Arellano & Genotoxicity, public health \\
\hline & Patricia Aceves & Cultural landscape \\
\hline & Ricardo Eaton & Environmental project \\
\hline & Gorgonio Ruíz & Ecology and biodiversity \\
\hline & Guillermo Aramburo & Urban planning \\
\hline & Ileana Espejel & Coastal zone management, regional planning \\
\hline \multicolumn{3}{|c|}{ Marine Sciences School } \\
\hline & Jose Luis Fermán & Coastal zone management, regional planning \\
\hline & Concepción Arredondo & \\
\hline & Alejandro García & \\
\hline & Georges Seingier & \\
\hline \multicolumn{3}{|c|}{ ALL TIMES COMPANIONS } \\
\hline \multicolumn{3}{|c|}{ Sociology and Business School } \\
\hline & Nelly Calderón de la Barca & Antropology, sociology, comunication \\
\hline & Alejandra Sánchez & \\
\hline & Concepción Martínez & \\
\hline & Sheila Delhumeau & \\
\hline & Lourdes Camarena & \\
\hline & Lilia Alemán & \\
\hline \multicolumn{3}{|c|}{ Oceanography Institute } \\
\hline & Leopoldo Mendoza & Water treatment, geohidrology, ecology of marine ecosystems \\
\hline & Walter Daessle & \\
\hline & Gabriela Montaño & \\
\hline \multicolumn{3}{|c|}{ Other Institutions (CICESE,COLEF) or Freelance } \\
\hline & Anamaria Escofet & $\begin{array}{l}\text { Ecology (ecophysiology, populations, communities, marine ecology, landscape ecology, and } \\
\text { landscaping) }\end{array}$ \\
\hline & Nora Marijena & \\
\hline & Stephen Bullock & \\
\hline & Martín Escoto & \\
\hline & Jesús Serrano & \\
\hline & Rosa Contreras & \\
\hline & Hugo Riemann & \\
\hline \multicolumn{3}{|c|}{ THESIS ADVISORS } \\
\hline \multicolumn{3}{|c|}{ Institutions mainly from Mexico and USA (California and Arizona) } \\
\hline & $\begin{array}{l}\text { Number of thesis directors or } \\
\text { codirectors }\end{array}$ & Mainly ecosystem management proposals plus many other topics \\
\hline
\end{tabular}

sciences (PNS; ISEE et al. 2008). As a result of such pragmatic formation, the MEZA ecosystem management plans and most recent theses have been developed with stakeholders and members of the "ejidos" (communal lands in Mexico;

Fig. 1. MEZA teachers and students of several teams.

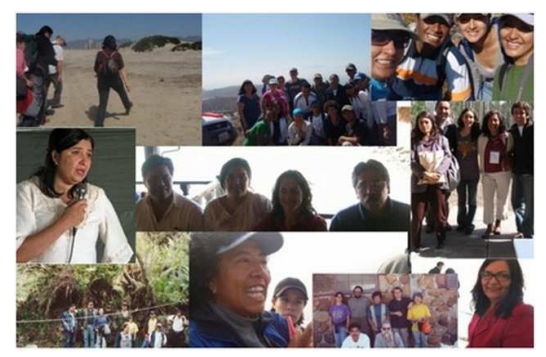

www.diputados.gob.mx/LeyesBiblio/pdf/13.pdf), fishing cooperatives, private landowners, and local governments to solve a perceived problem. Students have learned at MEZA that most environmental problems can only be solved when they are socially perceived. In general, MEZA research starts by identifying effects, not causes (Diamond 1983), and involves searching for multiple causes, and relating them to possible solutions, instead of a single cause.

The study and management of ecosystems and sustainable development has led to multidisciplinary approaches (e.g., Quinlan and Scogings 2004, Chávez-Cortés and ChávezCortés 2006, Tamayo y Tamayo 2011), and teams were constructed as represented during the transdisciplinary process (Morse et al. 2007; Fig. 2). Integrated research commonly refers to a process of coordinated, collaborative, or combined inquiry that develops sharing, creation, and synthesis of knowledge among disciplines, researchers, and the 
community or the stakeholders who need the environmental problem solved (Morse et al. 2007).

Fig. 2. Comparison among three types of multidisciplinary studies (taken from I. Espejel lessons).

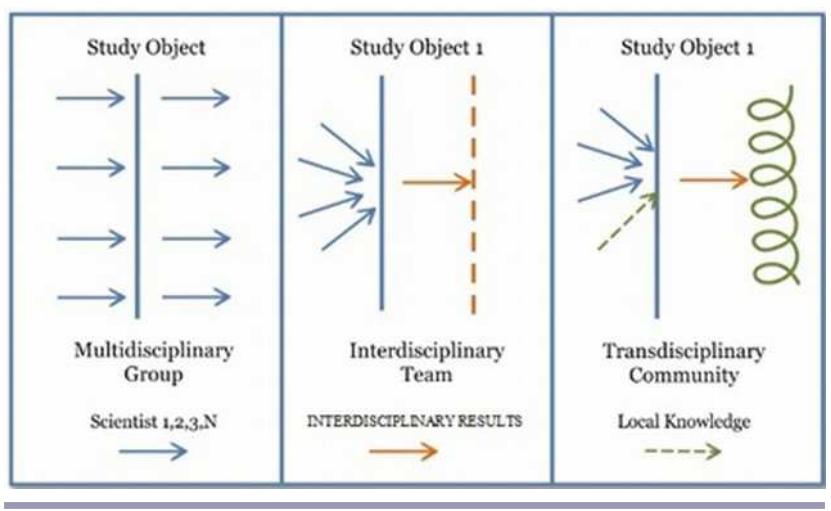

MEZA teaches ecosystem management planning in a "learn by doing" process while forming interdisciplinary teams and transdisciplinary communities. The process starts by acknowledging that MEZA students have a two-year scholarship, funded by Mexican taxes. When people from an ejido require studies, students and teachers have the ability to work on the required research. It is necessary to understand two perspectives. First, for the society and stakeholders who need the scientific study, the work performed by MEZA is free. However, students receive a scholarship and teachers a salary, both of which are funded by taxes paid by the people requesting the research. Therefore, students become aware of their responsibility and the community realizes the actual value of the proposed recommendations.

\section{MEZA PROGRAM CURRICULA}

At the Master of Science level, multidisciplinary teaching and thesis projects are possible, especially in the environmental planning arena; two years is sufficient to develop multidisciplinary training and an ecosystem management plan but not a long-term community compromise.

Groups of 12 to 17 students of the most diverse disciplines, for example, administrators, biologists, designers, educators, economists, engineers, oceanographers, sociologists, are formed. These multidisciplinary groups consist of students of comparable age and region of origin, and are gender diverse. The first year involves learning teamwork through courses intended to provide the key knowledge in ecological and social sciences, which are considered to be the basis for ecosystem management. The students also learn other environmental science tools, such as biostatistics, qualitative techniques, geographic information systems, environmental impact, and regional planning methodologies (Table 2). In this phase, the elaboration of an ecosystem management plan acts to unify the student and teacher groups. Notably, from the start and in accordance with Pickett et al. (2007), students are taught to answer the questions asked by society (important questions), not by the student or his/her teacher (interesting questions). At the end of the first semester, the multidisciplinary group is transformed into an interdisciplinary team. At the end of the first year, the ecosystem management plan is delivered to the petitioner; the plan provides a series of solutions (projects) that should be implemented in the transdisciplinary community. This project phase is considered the main success of the MEZA group in translating multidisciplinary science theory into practice.

During the second year, students concentrate on preparing an individual thesis in collaboration with a committee composed of three to five professors from diverse disciplines. It is the student's responsibility, helped by his/her advisor, to maintain multidisciplinary thinking within the thesis committee. Initially, the selection of experts in multidisciplinary thinking was not possible because the teachers were also being trained, but currently, the MEZA program prefers to select advisors with this type of expertise. A multidisciplinary approach requires flexibility, so only four courses and three thesis seminars are mandatory, whereas the rest are optional. The individualized program design is based on a tutor, who is a multidisciplinary-trained advisor, and a thesis director.

In this paper, our objective is to describe in detail the results of the first year phase. We will present some examples of MEZA's contributions to the management of arid-coastalurban ecosystems and the well-being of local people.

\section{ECOSYSTEM MANAGEMENT PLANS}

Any ecosystem management plan is understood through the complexity of the three spheres of sustainable development (Fig. 3), and this framework is intended as an integrated objective that can be achieved by the reconciliation of economic goals, social needs, and natural components (Montoya et al. 2009). Each sphere has more spheres within it: social (cultural, administrative, legal, political, etc.), economic (the projects are mainly microeconomic within a macroeconomic context and also include technological issues), and natural (biotic and abiotic). Because the ecosystem management plan is based on an issue presented by a community or stakeholder (first level in Fig. 3), the problem must be reformulated by the multidisciplinary student group, considering their disciplines and capabilities. At this stage, students think about the problem according to their disciplinary training, substantial interaction and discussions occur in class, and many questions emerge around the other "unknown" spheres. In this phase, students discover that there are other ways of solving the problem based on different disciplines. When this happens, interdisciplinary thinking arises (second level in Fig. 3). At this time, students and teachers interact with the community and learn ethnographic 
Table 2. Study plan of MEZA program.

\begin{tabular}{|c|c|c|c|c|}
\hline \multirow[t]{2}{*}{ Teachers } & \multicolumn{2}{|c|}{ First year } & \multicolumn{2}{|c|}{ Second year } \\
\hline & Semester 1 & Semester 2 & Semester 3 & Semester 4 \\
\hline Ileana Espejel & Ecology, integration & Ecosystem Management & & \\
\hline Jesús Serrano & Ecology, landscape & & & \\
\hline Gabriela Montaño & Ecology, ecosystems & Thesis workshop & & \\
\hline Claudia Leyva & Ecology, communities & & & \\
\hline Roberto MartÍnez & Ecology, terrestrial interactions & & $\begin{array}{l}\text { optional lectures related } \\
\text { to individual research }\end{array}$ & \\
\hline Anamaria Escofet & Ecology marine interactions & & & Thesis workshop \\
\hline Nora Marijena & Ecology, populations & $\begin{array}{l}\text { Optional lectures related to } \\
\text { individual research }\end{array}$ & & \\
\hline Martín Escoto & Ecology, organisms & & & \\
\hline Evarista Arellano & Biostatistics & & & \\
\hline Patricia Aceves & Social Sciences Techniques & & & \\
\hline Ricardo Eaton & Project Preparation & & & \\
\hline Jose Luis Fermán & & & Thesis workshop & \\
\hline
\end{tabular}

techniques (third level in Fig. 3). An interesting result is the surprise when individual students' findings are compared with the commentary, perception, and knowledge of the other students. At this moment in the process of the ecosystem management educational project, there is reconciliation between rationalism and empiricism (Bunge 1960) because the scientists prove their knowledge in the real world and obtain new information, as mentioned by Morse et al. (2007). The second and third levels are repeated constantly during the first and second semesters until there is cooperation between the natural and social sciences paradigms.

One of the most interesting results during this phase is that environmental education occurs for all participants. According to teacher Espejel, the community learns about the knowledge of others; "the transformation phase, when we [social and natural scientists] become more humble to the local knowledge and local people learn what scientists have to say. At this stage, scientists must ensure that the scientific knowledge published in English or Spanish is understandable." Therefore, during the twenty years of the program, students have had to translate all of the necessary scientific knowledge to a common understandable language (e.g., Fig. 4). This environmental education has not yet been evaluated, but not only have we heard from local people how these projects helped them initiate change in their communities, government stakeholders have mentioned how they have incorporated the ideas into their plans.

The main result is not only the discussion and development of conclusions about the problem, it is the construction of a useful ecosystem management plan required for funding institutions. Most people in the communities expect one solution to their problem; however, the multidisciplinary educational process provides multiple possible solutions. Therefore, the ecosystem management plan consists of producing a series of diverse projects and "instructions." For instance, these may be ideas for environmental businesses, recommendations for mitigating environmental problems, protected areas, wildlife management area designs, special environmental education programs, maps, GIS, flora and fauna lists, laws and bylaws interpreted in communication clusters, even address books, phone or e-mail directories of key people to contact in the intricate bureaucracy to obtain permits.

The convergence point (fourth level in Fig. 3) occurs when the student-teacher teams introduce to the community and/or stakeholders their ideas of how to solve the problem. At this moment the users of the ecosystem management plan express whether the proposed plan solves their problem or state that it was not what they expected from the academics and students. Teachers have mentioned that this could happen, even if these users participated in the process; an example given was a case with the Paipai Indian community for which the problem could not be solved because its origin was long in the past. Whatever the result, the new interaction could provide a new starting point from which the work can be continued by another group.

A series of successful projects in the urban-suburban and rural ecosystems of Ensenada were selected as examples. Also other ecosystem management plans are available in Spanish (http:// meza.ens.uabc.mx/ProductividadEST.htm).

\section{THE CHALLENGE: GREEN AREAS IN AN ARID COASTAL CITY}

Three ecosystem management plans dealt with a proposal to improve the greening of a semiarid city, in qualitative and quantitative terms. There is a lack of green areas in arid and semiarid cities in developing countries and Ensenada is not an exception. It has 65 parks representing 60.76 ha, which amounts to only $1.52 \mathrm{~m}^{2}$ per inhabitant. There is a $7.48 \mathrm{~m}^{2}$ 
Fig. 3. Diagram showing the dynamics among all participants when elaborating an ecosystem management plan. The first phase of MEZA program (first two semesters).

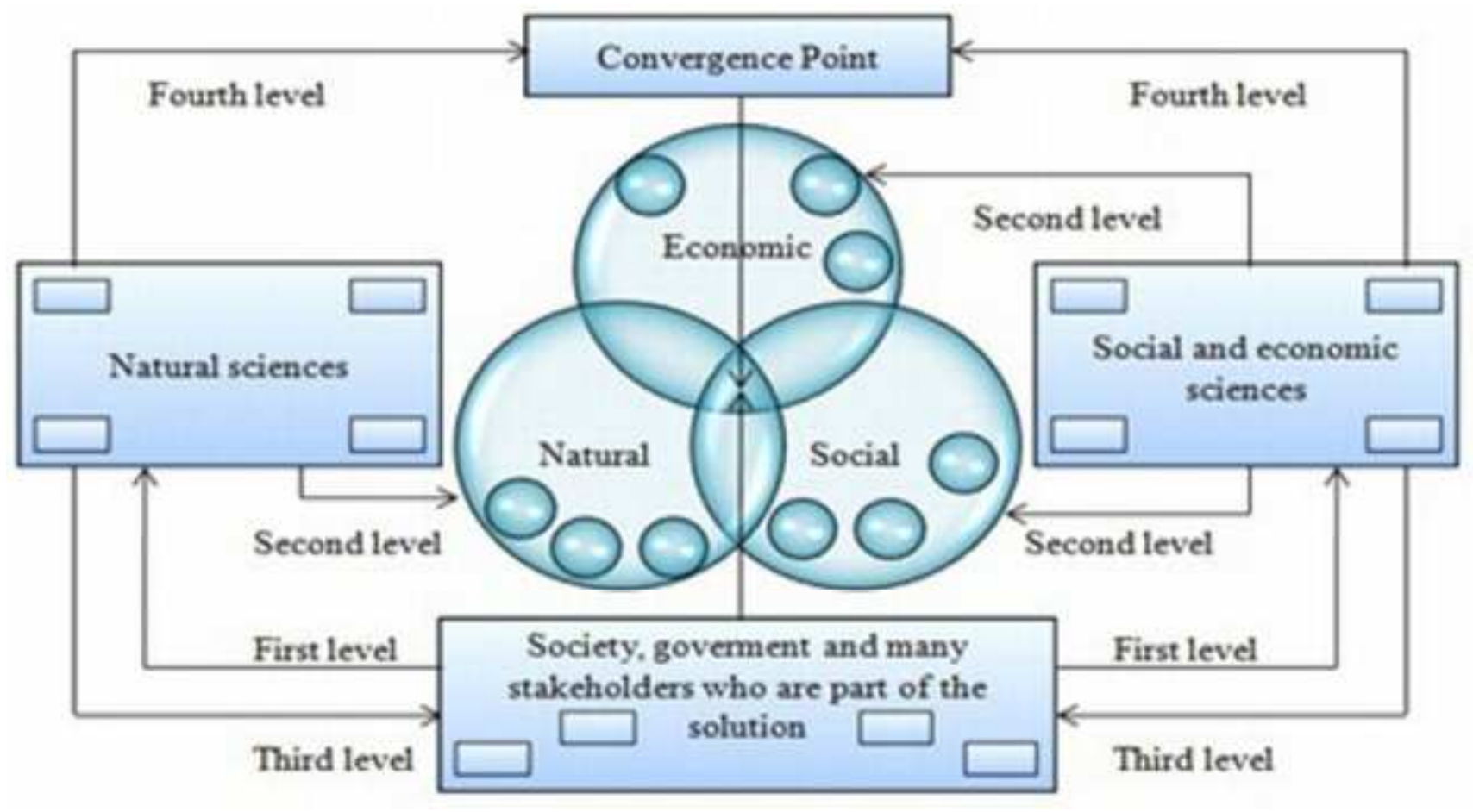

deficit of green area per inhabitant (according to Agenda 21, http://agenda21 ens.cicese.mx/agenda21local.htm). The Municipal Planning and Research Institute of Ensenada (IMIP)

Fig. 4. Comic depiction of laws on native plants.

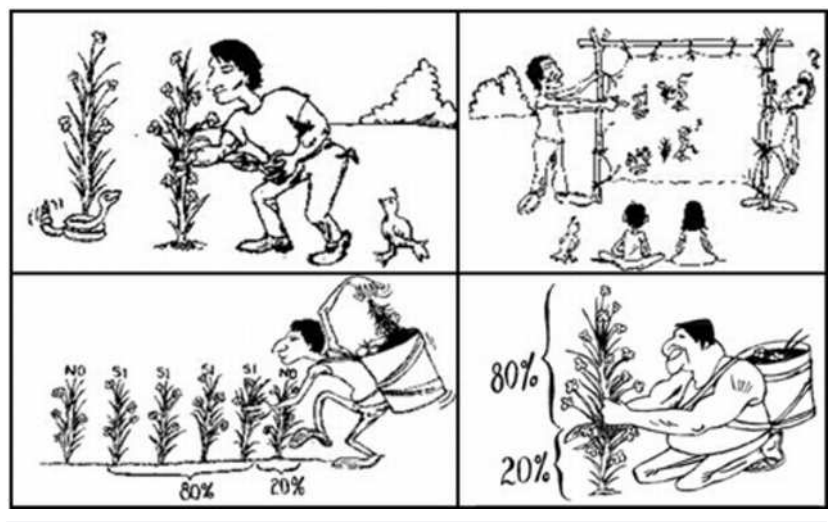

asked the MEZA teachers to propose ways to improve the green area indicators for the city. For this purpose, the city polygon was treated as an ecosystem with social, physical, and biotic areas, as described by Nilon et al. (2003). The proposal was divided into two categories: parks, with exotic species and infrastructure for recreation and services, and natural areas of native vegetation, which consisted of chaparral and coastal sage scrub in remnants within the city and ephemeral streams, "arroyos," that crisscrossed the city and were surrounded by the only tree-dominated vegetation.

\section{Greening Ensenada project AVEns (Areas Verdes de Ensenada)}

In 2005, AVEns was a project for park improvement. Parks were counted, measured, described, and analyzed, resulting in a classification consisting of three quality levels. Level one consisted of those parks that needed more time and funding to become the optimum park as defined by the citizens of Ensenada; the optimum park definition approximated the traditional park idea that comes from temperate landscapes with trees, flowers, plenty of grass, infrastructure, and services. Level two consisted of those parks that required less input and could reach the defined optimum in a moderate length of time, and level three included the few large and wellmaintained parks that closely resembled the park idealized by local people. The proposal included a GIS analysis and a very complete strategy with legal inputs, organization, and funding sources designed to achieve the goal of increasing the number and quality of the parks, but not the green area deficit. In fact, the present Ensenada municipal authorities are carrying out this project; they have elaborated an Urban Development Program (PDUCP-2030) and incorporated the results of the AVEns project (IMIP 2009). Nevertheless, IMIP realized that 
Fig. 6. El Campillo eroded temporal river (taken from MEZA-UABC 2010).

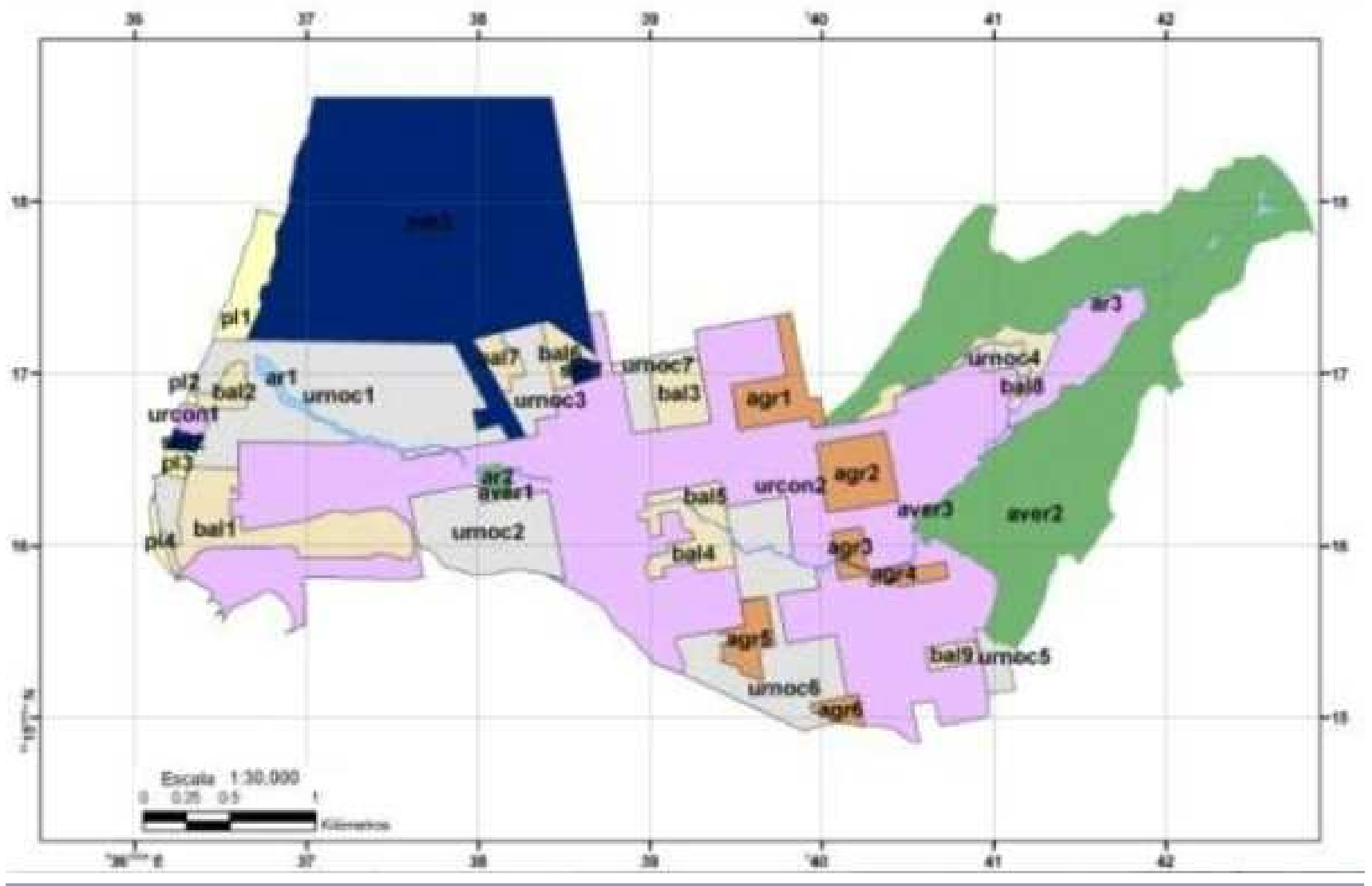

other types of parks were needed. Therefore, the next studentteacher groups made an ecosystem management plan for the natural areas within and surrounding the city.

\section{The natural remnants rescue: ANUEns project}

The objective of the ANUens (Areas Naturales Urbanas de Ensenada) project was the incorporation and reevaluation of natural area remnants within the city. This idea had to be further divided because ephemeral streams needed different strategies than chaparral and coastal sage scrub. Natural vegetation remnants had been studied by one MEZA teacher (Leyva et al. 2006, 2010, Leyva 2009) and as indirect components of other student projects. Because of limited space, these projects are not described thoroughly, but they have influenced the IMIP to consider the city of Ensenada to be an urban ecosystem, where dry vegetation could be as beautiful as artificial green parks. Coastal sand dunes and steep slopes within the city are considered "protective areas" (to protect the people), and other remnants are protected as natural areas for biodiversity.
Ephemeral rivers project: Arroyos

The ARROYEns Project was the proposal to recover ephemeral streams in Ensenada. In this project, three strategies were developed to build three different kinds of parks in the southern part of the city. Ensenada is interwoven by 10

Fig. 5. Risk and vulnerability zones in the Campillo (taken from MEZA-UABC 2010).

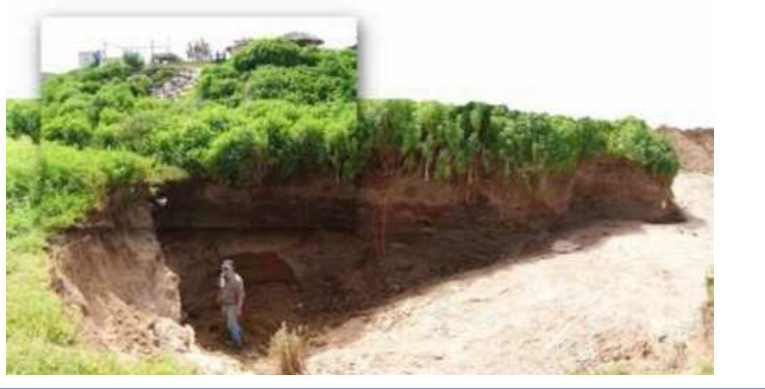


ephemeral streams that function mainly in pluvial drainage and transport of sediments to the municipal beach. These ecosystems are habitat to the only tree species in the shrubby landscape that characterizes the semiarid type of natural spots within the city. Because these ephemeral streams are dry most of the time, people forget the intensity of the rain and build over the dangerous terrains (Fig. 5), despite a law forbidding it.

An antecedent for this project was proposed by the 2008 student-teacher team for the northern part of the city, Arroyo San Miguel. The plan has been appropriated by the local residents and supported by the PRONATURA NGO. They have enlarged the park and obtained funding and legal support (www.elvigia.net/noticia/convierten-arroyos-en-parques).

In the 1990s, the neighbors of one of the most transformed arroyos organized the Chapultepec Ecological Committee to create a natural park, El Campillo, focusing on a small patch close to the beach, because of the lack of green areas within the city. The Mexican Water Commission asked them to present "a project." Because they did not know how to elaborate such a project, they asked MEZA for assistance. Their idea was to build a sightseeing spot and recreational activities.

Fig. 7. Ecological and social research in the Campillo (taken from MEZA-UABC 2010).

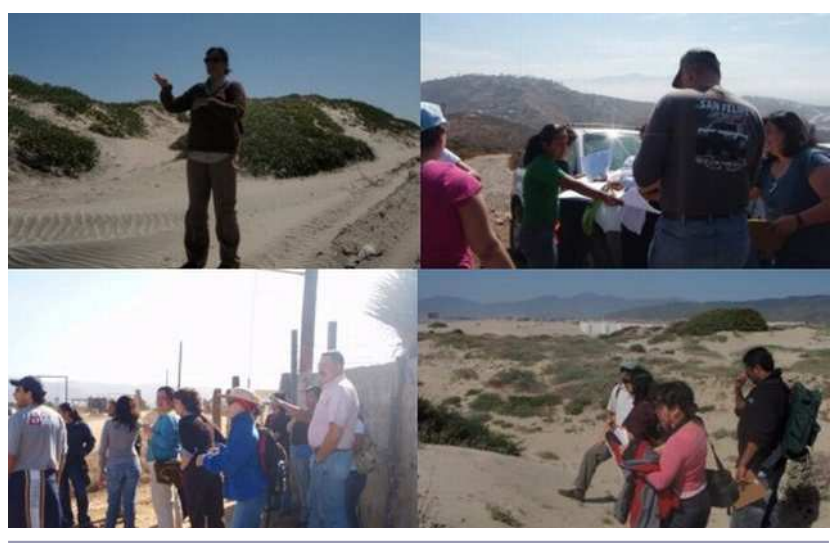

Our ecosystem management plan (2009 team) included three scales or projects: (1) macro scale, wherein the ephemeral streams were analyzed by state-stress-response scheme (PDUCPE-2030), (2) mesoscale, wherein the impacts and threats to the Escorpión-El Campillo stream were analyzed and considered in the design of linear parks, and (3) micro scale, wherein we compared recreational aptitudes with the actual land use (Fig. 6). The project analyzed the eroded, almost unvegetated arroyo and proposed regeneration activities including the reuse of water, a menu of different types of recreation, many of which were linked to environmental educational activities, and various designs for the infrastructure and recreational services (Fig. 7). Our study was the key in obtaining the area for the park. Now the community has the sightseeing spot (infrastructure) they demanded and the park is under construction. To incorporate ecosystem management paradigms, the plan included a wider vision of the park, the ecosystem to which El Campillo belongs, and the whole ephemeral stream (Escorpión) that had been interrupted by houses and streets causing flooding when it rained. This coarse-scale project included several ideas to restore the natural flow and incorporate other parks along the arroyo. To enlarge the ecosystem concept, the third project provided practical recommendations to convert the natural arroyos to linear parks within the city. This scaling approximation was crucial in achieving the concession of the area, because El Campillo was considered to be a pilot linear park.

The success of this plan is measured by the appropriation of the idea by the local organization. Despite the fact that their own first idea was based only on infrastructure, they accepted a larger project that considered the management of the whole riparian ecosystem rather than their own small backyard park. In this plan, the most rewarding contribution to our training was the social participation. People from the study site remained fascinated with the project (Fig. 8).

Fig. 8. The Municipal Planning and Research Institute of Ensenada (IMIP), Water Commission, congressman, and local stakeholders who asked for the El Campillo Project; teachers and students of MEZA program.

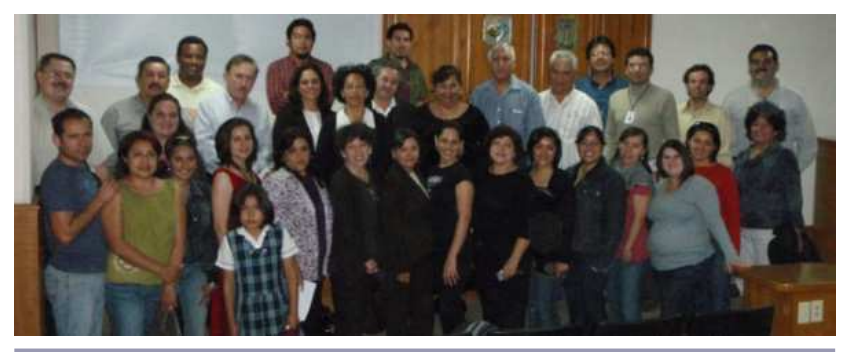

The decision makers and authorities attended the presentation and validated our proposal (www.elvigia.net/noticia/conviertenarroyos-en-parques). We consider this to be practical evidence of the MEZA philosophy acting together with the aspirations of the local people. In fact, the authorities in Ensenada have included this management plan in their strategies for the Ensenada Urban Development Program (IMIP 2009).

\section{ECOTOURISM TO PRESERVE LOCAL LAND OWNERSHIP AND ECOSYSTEMS BIODIVERSITY}

The most recent project was for the Ejido Coronel Esteban Cantú, in the rural area of southern Ensenada (Fig. 9). In August 2010, the leader of the community asked MEZA for 
technical expertise in identifying the natural resources of the ejido (Fig. 10) to develop their incipient apiculture. He said, "we can all obtain some benefits because you are students of the master's program, therefore you can help us with academic and technical instruction, and we can also provide you the space and facilities in the ejido to realize your university practices." The most important issue we (the 2010 team) heard was, "we want you to tell us what we can do in our ejido so we don't have to sell it." This is currently a common problem in rural areas because baby boomers from the U.S. are buying their land at low cost. These remarks made a perfect starting point for multidisciplinary studies and ecosystem management proposals.

Fig. 9. Observation work in the ejido.

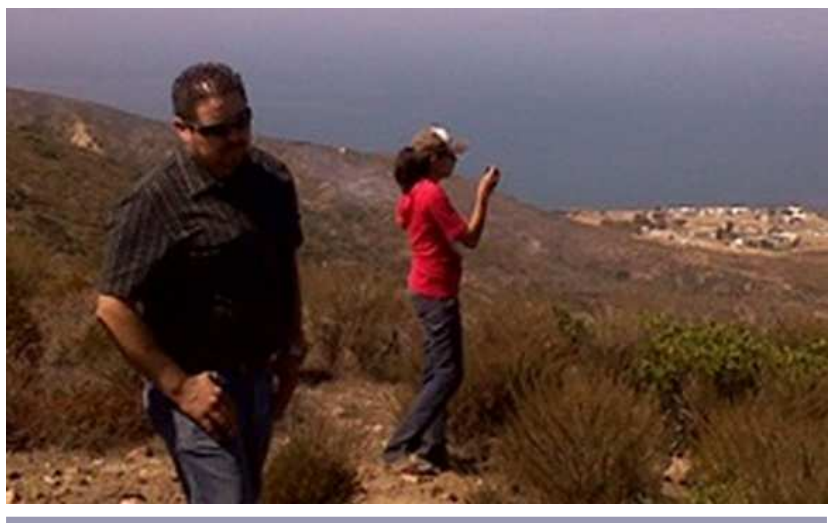

Fig. 10. Natural and scenic resources.

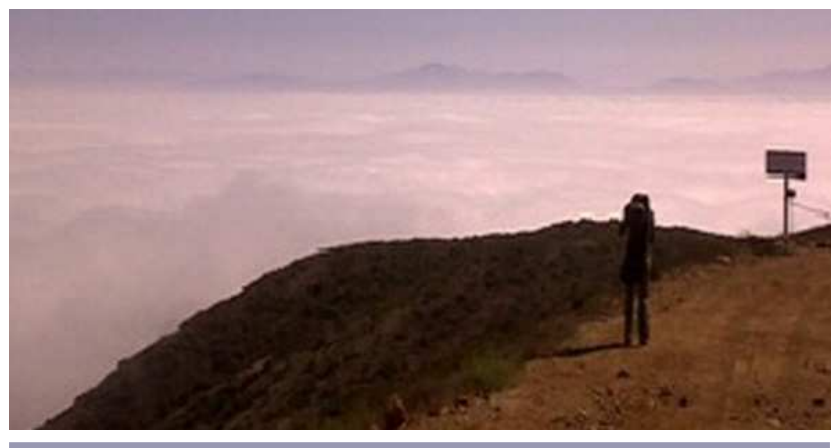

After the first meeting, the MEZA students had to investigate the most common environmental problems in the ejido to place the apiculture issues in context. The first part of the research was to characterize the social and ecological state of the ejido and to search with other "ejidatarios" for more projects that they were willing to have. Through this ethnographic (Fig. 11) and ecological research (Fig. 12), four projects emerged, of which apiculture was desired the most. However, four months later, when we presented our results a new leader arrived. "Comisario ejidal" changes every three years. The new leader was interested in ideas that were different from those of the former leader. Therefore, the apiculture project had to be adapted to a new political interest, ecotourism. It is important to mention that the new comisario ejidal is a woman, which represents a space gained by women. Her leadership demonstrates the empowering of women and signifies a new era in the behavior of the Mexican ejidos. Nevertheless, this did not change the political attitude shared by most leaders in that they want their own idea to prevail over those of the former leader. Among the projects there was a petition for an ecotourism business plan in a "communal space that can be used by all the ejidatarios for different activities and personal interests." This was the first situation in which opposition occurred among the groups of ejidatarios, because some wanted activities like apiculture whereas others wanted ecotourism.

Fig. 11. Ethnographic research in the ejido.

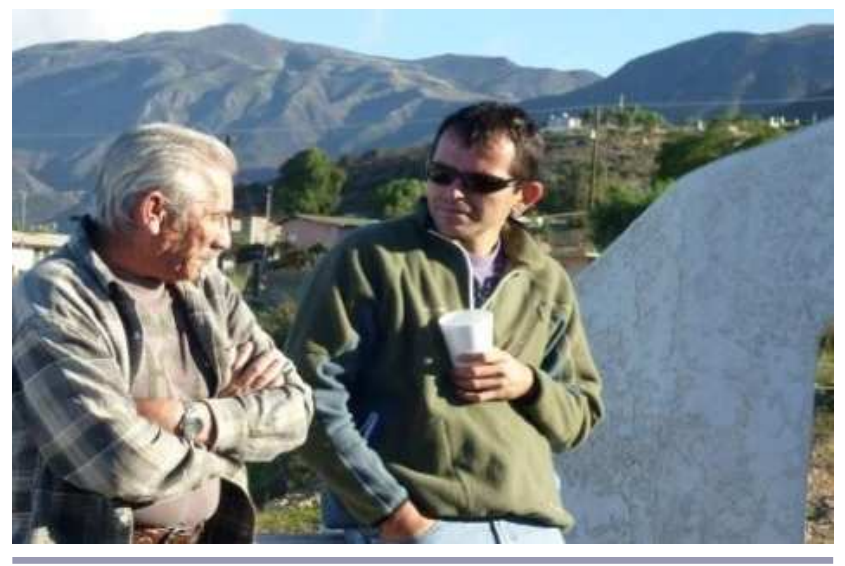

Fig. 12. Ecological research in the ejido.

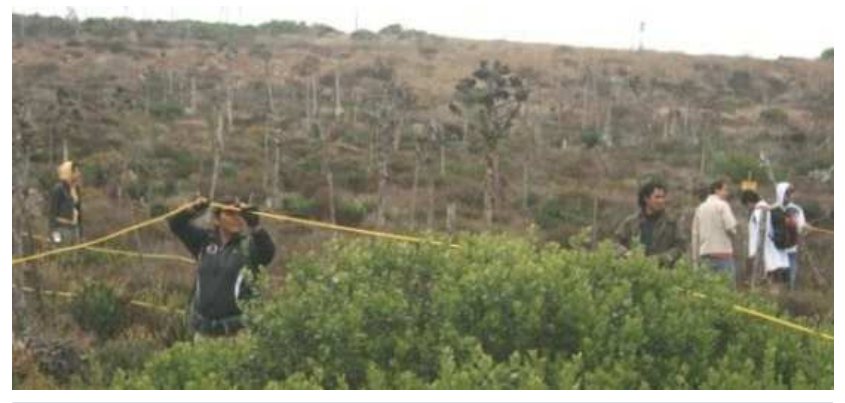

The most interesting creative work for the ecosystem management plan was to design a proposal attending to both necessities and wishes. The delivered plan included biological, 
social, and economic information, plenty of thematic cartography and a photographic album of the ejido, which is useful for any business project they might create. Likewise, there was a map with the collective imagery created by all of the participants (Fig. 13). There was a flora list for apiculture. There was also an ecotourism business plan, with all of the requirements to apply for road improvement; this need was mentioned several times and because there was one topographer in the team we could prepare the format and requirements for the petition. Additionally, there was a projection of the capital gain that provided encouragement not to sell their land and to instead apply for one of the projects we suggested in the ecosystem management strategy.

Fig. 13. Collective imagery by ejidatarios (taken from MEZA-UABC 2011.)

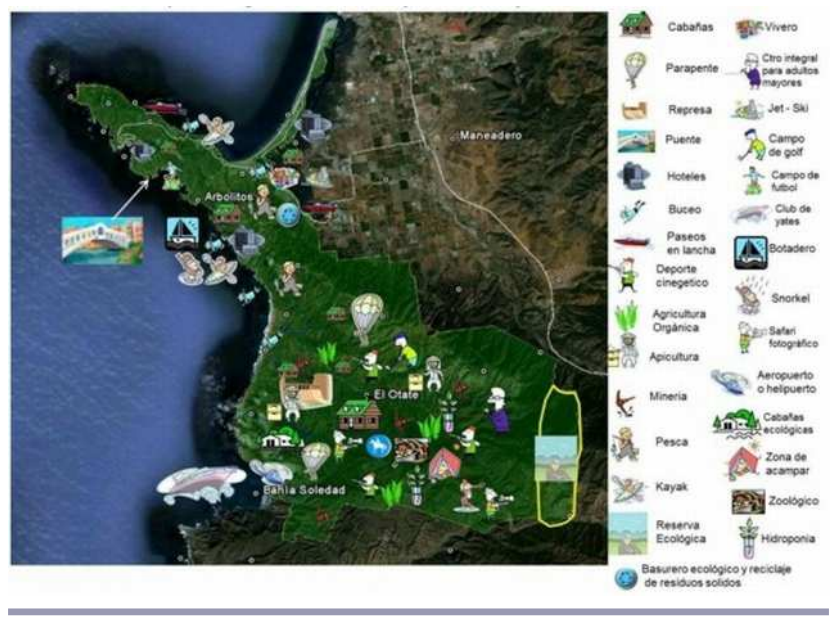

At the end the ejidatarios showed their approval and support for the management plan generated by the team (Fig. 14). Furthermore, we were convinced of the importance of the MEZA teaching techniques and hope that others will recognize their effort and commitment, which has been applied to 196 students and many communities within Ensenada and beyond in the last 20 years.

Fig. 14. Meeting with the ejidatarios (taked from MEZAUABC 2011).

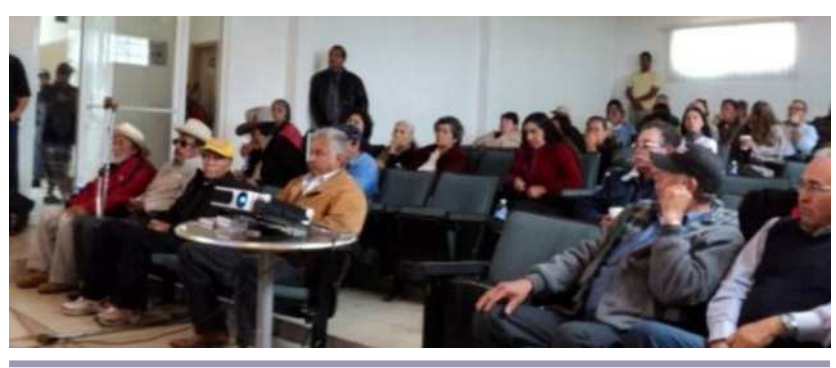

\section{CONCLUSION}

Management of arid ecosystems is a Master of Science program with 20 collective ecosystem management plans, each with several projects, that have influenced regional development, particularly in the semiarid city where the university is located.

The MEZA program accepts students from diverse disciplines and seeks different personalities in its teams because there is a necessity to factor an individual's vision into issues of risk taking, flexibility, a common vision, creativity, and crossdisciplinary thinking. There are leaders, integrators, finishers, and even individuals whose function is to wake the team by bringing coffee, cookies, and jokes. Everyone has a function in the process, every function is as important as the others, and every person collaborates in his or her work. It may sound easy, but it is not.

Ecosystem plans continue to address inquiries by the local communities and/or government, linking scientific and empirical knowledge with the decision making processes. Science is necessary for the proposals, but science is not enough; social participation and the inclusion of decision makers in the multidisciplinary process are the necessary conditions for achieving successful results and integrating concepts about sustainable development. Twenty years of MEZA experience has to be shared with others because we believe it has been a successful enterprise by a creative and energetic team of teachers.

Responses to this article can be read online at: http://www.ecologyandsociety.org/voll6/iss4/art19/ responses/

\section{Acknowledgments:}

We acknowledge Ileana Espejel and Claudia Leyva who provided information about past projects, which was important for writing this article. Additionally, they have been and will continue to be an elemental part of the MEZA staff. Likewise, to Evarista Arellano, Roberto Martinez, Ricardo Eaton, and every person who has contributed to MEZA's success, because the projects, impacts, and many benefits it has had in northwest Mexico are and will continue to increase human well-being.

\section{LITERATURE CITED}

Bunge, M. 1960. La Ciencia: su método y su filosofía. Universidad de Buenos Aires, Buenos Aires, Argentina. [online] URL: http://www.aristidesvara.net/pgnWeb/metodologia/ metodo_cientifico/naturaleza_metodo/bunge libro_aristidesvara. pdf

Chávez-Cortés, M. M., and J. M. Chávez-Cortés. 2006. La influencia de la transdisciplinariedad en el manejo de los 
recursos naturales y la conservación. Sociedades Rurales, Producción y Medio Ambiente 6(13):51-73.

Chircop, A. 2000. Teaching integrated coastal management: lessons from the learning arena. Ocean \& Coastal Management 43(4-5):343-359. http://dx.doi.org/10.1016/S09 $\underline{64-5691(00) 00032-6}$

Diamond, J. M. 1983. Ecology: laboratory, field and natural experiments. Nature 304:586-587. http://dx.doi.org/10.1038/3 $\underline{04586 \mathrm{a} 0}$

Espejel, M. I., C. Leyva, E. Arellano, G. Arámburo, R. Martínez, J. L. Fermán, and C. Arredondo. 2005. Evaluating interdisciplinary teaching and research in developing countries. Interdisciplinary Environmental Review 7 (1):82-90.

Instituto Municipal de Investigación y Planeación de Ensenada B.C.(IMIP). 2009. Programa de Desarrollo Urbano de Centro de Población 2030. IMIP, Ensenada, Baja California, México. [online] URL: http://www.imipens.org/IM IP files/PDUCP-E2030-abreviado.pdf

International Society for Ecological Economics (ISEE), S. Funtowicz, J. Ravetz, and R. Costanza. 2008. Post-normal science. In C. J. Cleveland, editor. Encyclopedia of Earth. Environmental Information Coalition, National Council for Science and the Environment, Washington, D.C., USA.

Leyva, C., I. Espejel, A. Escofet, and S. H. Bullock. 2006. Coastal landscapes fragmentation by tourism development: impacts and conservation alternatives. Natural Areas Journal 26(2):117-125. http://dx.doi.org/10.3375/0885-8608(2006)26 [117:CLFBTD]2.0.CO;2

Leyva, C. 2009. Estrategia para la gestión urbana de espacios de vegetación nativa con fines multifuncionales: caso de estudio Centro de Población de Ensenada, B.C. Dissertation. Universidad Autónoma de Baja California, Ensenada, Baja California, México.

Leyva, C., M. C. Arredondo, S. Delhumeau, M. I. Espejel, M. E. Arellano, and M. A. Sánchez. 2010. Apropiación de Espacios naturales como espacios públicos: estrategías de comunicación para la educación ambiental en Ensenada. Technical report. Facultad de Ciencias, Universidad Autónoma de Baja California, Ensenada, Baja California, México.

Maestría en Manejo de Ecosistemas de Zonas Áridas (MEZAUABC). 2010. Parques lineales en arroyos de Ensenada. Facultad de Ciencias, Universidad Autónoma de Baja California, Ensenada, Baja California, México. [online] URL: http://meza.ens.uabc.mx/ProductividadEST files/archivos/ ARROYEns.pdf
Maestría en Manejo de Ecosistemas de Zonas Áridas (MEZAUABC). 2011. Propuesta de Manejo para el Ejido Coronel Esteban Cantú Ensenada, Baja California, México. Facultad de Ciencias, Universidad Autónoma de Baja California, Ensenada, Baja California, México. [online] URL: http://mez a.ens.uabc.mx/ProductividadEST files/archivos/Plan $\% 20 \mathrm{de} \%$ 20Manejo\%20Final\%202011.pdf

Montoya, G., A. Minerva, J. F. Hernádez, and J. U. García. 2009. El sector forestal en Chiapas: un análisis desde la perspectiva de la economía ecológica. Revista Electrónica Nova Scientia 2(1):37-50.

Morse, W. C., M. Nielsen-Pincus, J. Force, and J. Wulfhorst. 2007. Bridges and barriers to developing and conducting interdisciplinary graduate-student team research. Ecology and Society 12(2): 8. [online] URL: http://www.ecologyandsociety. org/vol12/iss2/art8/

Nilon, H. C., A. R. Berowitz, and K. S. Hollweg. 2003. Introduction: ecosystem understanding is a key to understanding cities. Pages 1-4 in A. R. Berkowitz, H. C. Nilon and K. S. Hollweg, editors. Understanding urban ecosystems. A new frontier for science and education. Springer, New York, New York, USA. http://dx.doi.org/10.1007/0-387-22615-X_1

Pickett, S. T., J. Kolasa, and C. G. Jones. 2007. Ecological understanding: the nature of theory and the theory of nature. Elsevier Academic, New York, New York, USA.

Quinlan, T., and P. Scogings. 2004. Why bio-physical and social scientists cans speak the same language when addressing sustainable development. Environmental Science \& Policy 7:537-546. http://dx.doi.org/10.1016/j.envsci.2004.08.006

Tamayo y Tamayo, M. 2011. El proceso de la investigación científica. Limusa, Mexico City, México. 